\title{
Open Service Innovation: The Case of Tourism Firms in Scandinavia
}

\author{
Tor Helge Aas ${ }^{1}$
}

\begin{abstract}
Most empirical research investigating open innovation has focused on the development of new physical products in manufacturing industries, whereas open service innovation has not been researched correspondingly. Services have some characteristics that distinguish them from physical products, which may affect the types of open innovation practice utilised during service innovation processes. Tourism services comprise a subset of services that is particularly distant from tangible products. Therefore, the exploration of how tourism firms utilise different types of open innovation practice offers a valuable opportunity to learn about the nature of open service innovation practices. Thus, this paper addresses the following research question: what types of open innovation practice are utilised during the development of new tourism services? A qualitative case study approach was used to answer the research question. The findings suggest that pecuniary and non-pecuniary inflows of knowledge are utilised during service innovation processes in tourism. However, the stage of the innovation process at which inflows of knowledge are utilised varies systematically with respect to whether the innovation is perceived to be incremental or more radical. The findings also indicate that tourism firms reveal knowledge to other tourism firms in non-pecuniary outbound open innovation processes. However, no example of a pecuniary outbound open innovation practice was identified in this study. Implications for management and further research are discussed in the paper. Keywords: service innovation, new service development, open innovation, tourism management.
\end{abstract}

\section{INTRODUCTION}

Innovation is a critical factor for the generation of financial performance and competitive advantage in manufacturing (Adner \& Kapoor, 2010) and service (Aas \& Pedersen, 2010) firms. Therefore, the search for appropriate practices and strategies to organise and manage innovation activities is the focus of an ongoing stream of research. In a broad sense, empirical results of this

1 Tor Helge Aas, Ph.D., Associate Professor, School of Business and Law, University of Agder, Gimlemoen 19, 4630 Kristiansand, Norway, and Senior Researcher, Agderforskning AS, Gimlemoen 19, 4630 Kristiansand, Norway, e-mail: tor.h.aas@uia.no. 
research have confirmed that the characteristics of service innovation differ from those of product innovation (Droege, Hildebrand \& Forcada, 2009). Research results have also suggested that innovation practices differ among service subsectors (Kuester, Schuhmacher, Gast \& Worgul, 2013). Sectorial differences relate to the conceptual complexity of innovation (den Hertog, 2000), the innovation processes (de Brentani, 2001), and the resources needed to carry out these processes (Nijssen, Hillebrand, Vermeulen \& Kemp, 2006). The observed differences are often explained by the fact that services have, to varying degrees, specific characteristics such as intangibility, heterogeneity, inseparability, perishability (Zeithaml, Parasuraman \& Berry, 1985), and co-creation of value (Vargo \& Lusch, 2004), which in turn affect innovation practices.

In recent years, the potential of involving external actors in firms' innovation processes, often referred to as 'open innovation', has received much attention from researchers and business managers (Dahlander \& Gann, 2010; Huizingh, 2011). To date, however, most open innovation research has focused on manufacturing firms developing new physical products; open innovation practices of firms developing new services have not been researched correspondingly (e.g., den Hertog, van der Aa \& de Jong, 2010; Huizingh, 2011; Mina, Bascavusoglu-Moreau \& Hughes, 2014; West \& Bogers, 2014). Thus, our knowledge of open service innovation practices is limited (Huizingh, 2011). This literature gap is concerning, as service industries in most developed countries account for greater proportions of GDP and employment than do manufacturing industries (Spohrer \& Maglio, 2008), and due to the importance of innovation to firm-level success in service industries (Evangelista \& Vezzani, 2010).

To contribute to filling this literature gap related to open service innovation, Chesbrough recently published a book (Chesbrough, 2011a) and a series of conceptual articles (e.g., Chesbrough, 2011b) in which he discussed the relevance of open innovation in services. Using success stories from product innovation, he argued conceptually why open innovation may be beneficial also for innovation in services, and he concluded that 'open innovation accelerates and deepens services innovation' (Chesbrough, 2011b, p. 15). Empirical studies investigating Chesbrough's (2011b) proposition remain scarce, but a few exist. Some of these studies focus on particular subsectors, such as business services (e.g., Mina et al., 2014) and banking services (e.g., Gianiodis, Ettlie \& Urbina, 2014), whereas others focus on the service sector as a whole (e.g., Mention, 2011). On the whole, the results of these empirical studies support Chesbrough's (2011b) proposition. 
Despite these significant contributions, open service innovation remains a relatively unexplored area of research (Mina et al., 2014). In particular, more empirical insight is needed to understand more deeply the types of open innovation processes used during new service development. To contribute to filling this literature gap, we performed an in-depth qualitative study on a subset of services that is particularly distant from tangible products: tourism services (e.g., Hjalager, 2010). These services are arguably characterised by high degrees of intangibility, inseparability, perishability, and heterogeneity (Zeithaml et al., 1985), in part because tourism firms often add experiential components to their core offerings in the form of 'comprehensive living adventures' (Stamboulis \& Skayannis, 2003, p. 38). Thus, this qualitative examination of how tourism firms exploit different types of open innovation practice when they develop new services will provide valuable new insight on the broader topic of open service innovation. This study examined the following research question: what types of open innovation practice are utilised during the development of new tourism services?

The article is structured as follows. In the next section, we review the (product) innovation management literature on different types of open innovation practice. Based on the findings of previous empirical studies, service innovation in tourism is then distinguished from product innovation to (theoretically) suggest why such types of open innovation practice may, or may not, be relevant for service innovation activities in tourism. Thereafter, we describe the case study research method. In the following section, we report the research findings, describing the types of open innovation practice that were utilised during service innovation processes in our cases. The paper ends with a discussion of practical and theoretical implications and suggestions for further research.

\section{THEORY}

\section{Types of open innovation}

The term 'open innovation' refers to 'the use of purposive inflows and outflows of knowledge to accelerate internal innovation, and to expand the markets for external use of innovation, respectively' (Chesbrough, Vanhaverbeke \& West, 2006, p. 1). Chesbrough (2003, p. 24) argues that 'open innovation is a paradigm that assumes that firms can and should use external ideas as well as internal ideas, and internal and external paths to market, as firms look to advance their technology.' The first mechanism in this definition, i.e. the use of inflows of knowledge, is often called 'inbound' open innovation, whereas the second mechanism, i.e. the use of outflows of knowledge, is often called 
'outbound' open innovation (Huizingh, 2011). Based on a review of the literature, Dahlander and Gann (2010) also distinguish between pecuniary and non-pecuniary types, and consequently suggest four types of open innovation: 1) non-pecuniary inbound open innovation (sourcing), 2) pecuniary inbound open innovation (acquiring), 3) non-pecuniary outbound open innovation (revealing), and 4) pecuniary outbound open innovation (selling).

The research literature discusses benefits and disadvantages of these four types of open innovation. For example, the ability to buy external ideas or expertise (inbound pecuniary open innovation) has many benefits, as it may provide a firm with valuable resources that it would not have been able to obtain in other ways (Dahlander \& Gann, 2010). Research indicates, however, that the acquisition of knowledge that is too close to what the firm already knows may reduce the positive effects (Dahlander \& Gann, 2010). Inbound non-pecuniary open innovation may also be beneficial, as it provides opportunities for firms to benefit from the ideas of outsiders to generate new products or services (Dahlander \& Gann, 2010). As there are cognitive limits to how much individuals working within firms can understand, however, firms may risk relying too much on external sources of innovation, which may be a disadvantage (Laursen \& Salter, 2004). Furthermore, outbound pecuniary open innovation may have advantages, as firms can benefit more effectively from their investments in R\&D (Chesbrough et al., 2006), but a disadvantage is that significant transaction costs are often involved (Gambardella, Giuri, \& Luzzi, 2007). Outbound non-pecuniary open innovation enables firms to build upon each other's work and may result in increased innovativeness (Nuvolari, 2004), but the obvious disadvantage of revealing knowledge and ideas renders the capturing of benefits difficult (Helfat, 2006).

Recent literature reviews (Dahlander \& Gann, 2010; Huizingh, 2011; West \& Bogers, 2014), however, reveal that the open innovation research in which these advantages and disadvantages are discussed has investigated a limited sample of industries and sectors. According to a review by Aas and Pedersen (2016), research in this area has focused predominantly on the software, telecommunications, chemical, electronics/semiconductors, pharmaceutical, fast-moving consumer goods, aerospace, bioscience, sports goods, and apparel sectors. Thus, the four-type framework of Dahlander and Gann (2010) is based to a large extent on investigations of physical product innovation, and its relevance for new service development remains uncertain.

\section{The specificities of service innovation in tourism}

Some scholars have argued that innovation management research in general has been concerned primarily with the management of physical product 
innovation processes (e.g., Droege et al., 2009), and not the management of service innovation processes (Drejer, 2004; Adams, Bessant \& Phelps, 2006; Nijssen et al., 2006; Spohrer, 2008), and that this skewed focus has resulted in the status that 'current theory and understanding of the strategies and tactics for developing new services is inadequate' (Menor \& Roth, 2007, p. 825). Although this claim remains true to a certain degree, scholars are increasingly examining the characteristics of service innovation management, and how they differ from those of product innovation management (Johne \& Storey, 1998; Johnson, Menor, Roth \& Chase, 2000; Menor, Tatikonda \& Sampson, 2002).

A main topic in this research stream is the types of resources or capabilities firms need to succeed with new service development (e.g., den Hertog et al., 2010). Researchers have found, for example, that the involvement of frontline employees (Lages \& Piercy, 2012) and internal experts (Hydle, Aas \& Breunig, 2014), as well as the establishment of cross-functional teams, is often associated with successful implementation of service innovation projects (e.g., Droege et al., 2009). The research results also suggest that relevant training and assignment of innovative roles are critical success factors (de Jong \& Vermeulen, 2003).

The extant service innovation literature also suggests that external resources are important in service innovation processes (Williams \& Shaw, 2011). In particular, the involvement of (prospective) customers is often highlighted as an important source of innovative ideas and co-creators of new services (e.g., Carbonell, Rodríguez-Escudero \& Pujari, 2012; Gustafsson, Kristensson \& Witell, 2012). A few studies also highlight the importance of other types of external actor. Tsou (2012), for example, suggested that firms need competence for collaboration with external firms to succeed with service innovation. Research has also shown that service firms rarely carry out traditional R\&D internally (e.g., Meyer, 2010), although the implementation of R\&D-embodied technology is often a source of innovation in services, and in tourism services in particular (e.g., Orfila-Sintes et al., 2005).

Although the importance of external collaboration has been discussed to some degree in the service innovation literature, explicit exploration of the types of open innovation practice, according to Dahlander and Gann (2010)'s framework, that are utilised in new service development processes is largely missing (Aas \& Pedersen, 2016). We argue that the empirical exploration of open innovation practices related to the development of new tourism services constitutes a particularly relevant context with which to build knowledge in this area, as these services represent a subset of services far removed from tangible products (Stamboulis \& Skayannis, 2003; Zeithaml et al., 1985; Zomerdijk \& Voss, 2011). 
In a broad sense, innovation in the tourism sector may be defined as 'the generation, acceptance and implementation of new ideas, processes, products or services' (Hall \& Williams, 2008, p. 5). As noted by several authors, however, distinction among process, product, and service innovation in service industries can be difficult because 'new services often go together with new patterns of distribution, client interaction, quality control and assurance, etc.' (de Jong, Bruins, Dolfsma \& Meijgaard, 2003, p. 17). Therefore, 'service innovation' is often used as a generic term referring to many different types of innovation in service firms. In this paper, we thus base our exploration on a broad definition of service innovation suggested by van Ark, Broersma and den Hertog (2003, p. 16): 'a new or considerably changed service concept, client interaction channel, service delivery system or technological concept that individually, but most likely in combination, leads to one or more (re)new(ed) service functions that are new to the firm and do change the service/good offered on the market and do require structurally new technological, human or organisational capabilities of the service organisation.'

The specific characteristics of services in general, and tourism services in particular, may be expected to affect the types of open innovation practice that are relevant when new (tourism) services are developed. As indicated by extant research (e.g., Buhalis, 2000; Carbonell et al., 2012; Hall \& Williams, 2008), the inseparable nature of these services may, for example, imply that inbound open innovation practices in which knowledge from customers is used to accelerate innovation may be highly relevant for tourism firms. This proposition is also supported by empirical research. For example in a study of experience-based tourism Stamboulis and Skayannis (2003) found that first movers among the customers were an important source of knowledge during the innovation processes.

However, whether the intangible and perishable nature of these services implies that knowledge from other external actors is less relevant in these innovation processes is an open question. It could be argued that the knowledge of external actors not directly involved in the co-creation of services is too limited to contribute during innovation processes in tourism, and research has for example confirmed that tourism firms seldom use knowledge from universities and research laboratories during their innovation processes (Hjalager, 2010). However, in the recent times tourism firms have implemented much new technology both to streamline the internal processes and to improve the services provided (Hjalager, 2010), and it has been suggested that knowledge is embedded in this technology, implying that the implementation of new technology indirectly involves the transfer 
of knowledge from technology suppliers to tourism firms (Evangelista, 2000; Hjalager, 2000).

One may also question whether the intangible and perishable nature of tourism services also implies that outbound open innovation is less relevant. Research has indicated that an important characteristic of successful outbound open innovation is that it is possible to separate systems in specific modules of knowledge that can be sold or shared to other actors during innovation processes (Henkel, 2006). The intangible and perishable nature of tourism services may complicate modularization of tourism services, and this may reduce the applicability of outbound open innovation in tourism (Aas \& Pedersen, 2016). To explore these open questions about open service innovation practices in tourism and provide an initial view of how these practises look, relative to open innovation practices in manufacturing, we conducted an exploratory study focusing on tourism services.

\section{RESEARCH METHOD}

A qualitative case study approach (e.g., Yin, 2003) was chosen, as qualitative research arguably has advantages when the phenomenon to be studied is not well understood and when the variables remain unknown (e.g., Johnson \& Harris, 2003). To enable selection of case organisations that offered opportunities to learn and build theory, and to obtain a preliminary overview, two preliminary short interviews were conducted with managers of two Scandinavian networks of tourism firms. These informants were asked to identify firms in different subsectors of the tourism industry (e.g., accommodation, transportation, dining, and attractions) that had recently developed and commercialized new services. 15 tourism firms in Scandinavia were suggested in these interviews, and we decided to select all 15 firms as case organisations. All firms were members of at least one network focusing on business development and innovation, also indicating their interest in and focus on innovation. Two firms - one amusement park and one ski resort - provided purely experiential services. Six firms - two airlines, two cruise and transport shipping firms, one airport operation firm, and one railway firm - provided personal transportation services. Six firms (all hotel chains) provided accommodation and dining services. One firm, an independent hotel, provided accommodation services only, and one firm, an independent restaurant, provided dining services only. Firm size varied, with the number of full-time employees (FTEs) ranging from 11 (the independent hotel) to approximately 13,000 (a hotel chain). 
Data were collected mainly in in-depth interviews with employees involved with innovation in the case organisations. We approached the firms' representatives in the business networks, in practice often the CEOs, and asked whether they were interested in their firms' participation in the study. Representatives of all 15 firms responded positively to our request. They were asked to indicate preferred employees to be interviewed about the firms' innovation practices. These informants were CEOs in five cases and other members of the top management groups (e.g., CMOs, CTOs) in the remaining cases. During interviews with the appointed key informants, we also identified other relevant informants in the firms. These additional informants were interviewed at a later stage. As a result, one to five informants from each firm (30 in total) were interviewed. Table 1 lists the key characteristics of the sample.

Based on the framework of Dahlander and Gann (2010), we developed a semi-structured interview guide (Appendix A). During the interviews, the informants were asked to select a few new services that the firms had introduced recently. To capture inbound open innovation practices, informants were asked questions related to the sources of the new service ideas and to external collaboration during the innovation processes. To capture practices related to outbound open innovation, the informants were asked to describe the introduction of new services by other firms, in which their firms had participated. All interviews were recorded and transcribed, and the data were coded and mapped onto the four open innovation dimensions reflected in the framework of Dahlander and Gann (2010).

\section{FINDINGS}

Informants provided numerous examples of new or improved services introduced by the sampled firms during the interviews. Some were perceived to have high degrees of newness, whereas others were perceived to have lower degrees of newness (Table 1). Hereafter, we refer to innovations perceived by the informants to have high degrees of newness as 'radical', and those perceived to have low degrees of newness as 'incremental', although we realise that informants' perceptions are not necessarily aligned with more formal definitions of these terms (e.g., Henderson \& Clark, 1990; Gallouj \& Weinstein, 1997). We report our empirical findings according to the four dimensions of Dahlander and Gann's (2010) framework. 
Table 1. The sample of tourism firm representatives

\begin{tabular}{|c|c|c|c|c|}
\hline Firm & Type & FTEs & Informants & $\begin{array}{l}\text { Innovation examples (in } \\
\text { brackets: degree of newness } \\
\text { [high/low] as perceived by the } \\
\text { informants) }\end{array}$ \\
\hline A & $\begin{array}{l}\text { Accommodation and } \\
\text { dining (hotel chain) }\end{array}$ & 2700 & $\begin{array}{l}\text { CEO, hotel } \\
\text { manager }\end{array}$ & $\begin{array}{l}\text { Improvements of food } \\
\text { concept (low), improvements } \\
\text { of bed/pillow quality (low), } \\
\text { establishment of new hotels at } \\
\text { spectacular locations (high), new } \\
\text { experiential services (high) }\end{array}$ \\
\hline B & $\begin{array}{l}\text { Accommodation and } \\
\text { dining (hotel chain) }\end{array}$ & 12000 & CEO, CMO & $\begin{array}{l}\text { New food concept (low), new } \\
\text { marketing concept (low) }\end{array}$ \\
\hline C & $\begin{array}{l}\text { Accommodation and } \\
\text { dining (hotel chain) }\end{array}$ & 2000 & $\begin{array}{l}\mathrm{CEO}, \mathrm{CMO} \text {, sales } \\
\text { manager, hotel } \\
\text { manager }\end{array}$ & $\begin{array}{l}\text { Upgrading of hotel rooms (low), } \\
\text { new conference concept (high) }\end{array}$ \\
\hline D & $\begin{array}{l}\text { Accommodation and } \\
\text { dining (hotel chain) }\end{array}$ & 13000 & $\begin{array}{l}\mathrm{CEO}, \mathrm{CMO}, \mathrm{HR} \\
\text { manager, revenue } \\
\text { manager, hotel } \\
\text { manager }\end{array}$ & $\begin{array}{l}\text { New mobile check-out service } \\
\text { (low), new food concept (low), } \\
\text { improved revenue management } \\
\text { system (high), new housekeeping } \\
\text { procedures (low) }\end{array}$ \\
\hline$E$ & $\begin{array}{l}\text { Accommodation and } \\
\text { dining (hotel chain) }\end{array}$ & 1250 & $\begin{array}{l}\text { CEO, CMO, two } \\
\text { hotel managers }\end{array}$ & $\begin{array}{l}\text { New food concept (low), } \\
\text { new check-in concept (high), } \\
\text { establishment of a new hotel in a } \\
\text { new location (low) }\end{array}$ \\
\hline $\mathrm{F}$ & $\begin{array}{l}\text { Accommodation } \\
\text { (independent hotel) }\end{array}$ & 11 & $\begin{array}{l}\text { Chairman of the } \\
\text { board (owner) }\end{array}$ & $\begin{array}{l}\text { New concept for affordable hotel } \\
\text { accommodation (high) }\end{array}$ \\
\hline G & $\begin{array}{l}\text { Dining (independent } \\
\text { restaurant) }\end{array}$ & 29 & CEO & New food concept (high) \\
\hline $\mathrm{H}$ & $\begin{array}{l}\text { Experiential services } \\
\text { (amusement parks) }\end{array}$ & 160 & CEO & $\begin{array}{l}\text { New themed accommodation } \\
\text { concept (high), new dining } \\
\text { concept (low) }\end{array}$ \\
\hline I & $\begin{array}{l}\text { Experiential services } \\
\text { (ski resorts) }\end{array}$ & 950 & $\begin{array}{l}\text { CTO, director of } \\
\text { one ski resort, } \\
\text { innovation expert }\end{array}$ & $\begin{array}{l}\text { New ski park for children (high), } \\
\text { improvements of ski parks (low), } \\
\text { new lift capacity/quality (low), } \\
\text { new booking system (high), } \\
\text { improved preparation of ski } \\
\text { slopes (low) }\end{array}$ \\
\hline $\mathrm{J}$ & $\begin{array}{l}\text { Personal } \\
\text { transportation }\end{array}$ & 5700 & Director of sales & $\begin{array}{l}\text { New experiential travelling } \\
\text { packages (high) }\end{array}$ \\
\hline K & $\begin{array}{l}\text { Personal } \\
\text { transportation }\end{array}$ & 13000 & $\begin{array}{l}\text { Director of } \\
\text { revenue } \\
\text { management }\end{array}$ & $\begin{array}{l}\text { Improved loyalty programme } \\
\text { (high) }\end{array}$ \\
\hline $\mathrm{L}$ & $\begin{array}{l}\text { Personal } \\
\text { transportation }\end{array}$ & 1800 & $\begin{array}{l}\text { CMO, innovation } \\
\text { expert }\end{array}$ & $\begin{array}{l}\text { New experiential travelling } \\
\text { packages (high) }\end{array}$ \\
\hline M & $\begin{array}{l}\text { Personal } \\
\text { transportation }\end{array}$ & 2600 & $\begin{array}{l}\text { Director of } \\
\text { communications }\end{array}$ & $\begin{array}{l}\text { New experiential travelling } \\
\text { packages (high) }\end{array}$ \\
\hline $\mathrm{N}$ & $\begin{array}{l}\text { Personal } \\
\text { transportation }\end{array}$ & 8700 & $\mathrm{COO}$ & $\begin{array}{l}\text { New experiential travelling } \\
\text { packages (high) }\end{array}$ \\
\hline $\mathrm{O}$ & $\begin{array}{l}\text { Personal } \\
\text { transportation }\end{array}$ & 3000 & $R \& D$ director & $\begin{array}{l}\text { Improvement of safety (low), new } \\
\text { design of service facilities (high) }\end{array}$ \\
\hline
\end{tabular}




\section{Non-pecuniary inbound open innovation (sourcing)}

New service ideas were often 'born' outside the borders of the firms in our sample. Incremental ideas, often related to the improvement of existing services, typically came from existing customers and were often identified by front-line employees of the firms, or through surveys or other digital social media channels. Examples of incremental innovations that emerged from customer input/ideas are the establishment of a new dining concept (firm $\mathrm{H}$ ), the upgrading of accommodation facilities (firm C), and the improvement of ski parks (firm I). Purposive inflows of knowledge from customers in the early stages of the innovation process typically had a non-pecuniary nature. The following statements from two informants, from firms $C$ and I respectively, illustrate this practice:

'All our customers are given a questionnaire after they have visited us, and we get lots of insights on how to improve our products from their answers. (...) We are also working right now on how we can establish a better dialogue with our customers via different social media.'

'We have direct dialogue with our customers in the ski park all the time. I will say that we to a high degree have developed the park based on ideas from the users. In particular we involve customers that use our facilities often, for example cottage owners that spend much time here.'

External actors were also involved during the early stages of the development of more radical innovations, but this involvement was typically more indirect. For example, when reflecting on the early stages of the development of a new concept for themed accommodation (which he perceived to be a radical innovation), the CEO of firm $\mathrm{H}$ stated:

'When we work with innovation and development we pay attention to what is happening around us, we always look at what other firms are doing and we contact and visit the attractions that have what we believe are the best in the world in our industry, and we try to learn from them. (...) The idea to build themed accommodation as an extension of the experiences we already offer is in many ways my personal idea based on such visits to other parks.'

A similar practice may be illustrated by the following statement from our informant in Firm $\mathrm{K}$ when he reflected on the early stages of a new loyalty programme (which he perceived to be a radical innovation):

'We have made a new and very specific vision for frequent travellers and this innovation project is about reaching this new vision. (...) The new vision was made by the top management, it was a top-down initiative, but of course we got input from different departments during the early process and we were also inspired by an actor in another industry who had a similar vision (...).' 
Thus, our empirical findings indicate that external actors were often sources of inspiration during the early stages of more radical innovation processes in the case organisations, but that direct and purposive knowledge transfer from an external actor to the innovating firm seldom took place at this stage. In later stages of radical innovation processes, however, we identified purposive non-pecuniary inflows of knowledge in several of the examples presented during the interviews. During the development of the themed accommodation concept mentioned above, for example, firm $\mathrm{H}$ decided to involve existing and prospective customers as participants in focus groups. This involvement was valuable and affected the final service design in many ways, as explained by the firm's CEO:

'After we had decided to invest in this project, after the initial conceptual phase, we travelled around in Norway to present our new concept to invited focus groups. The focus groups consisted of an existing customer base and some who had not been customers before. Between 12 and 20 people participated at each location (...). And first I presented what we had planned to do (...). Then I said to the focus group members: now you can have five minutes to tell why you think this is great (...). Thereafter we spent an hour together to discuss what was wrong with the concept. (...) And the results of this exercise were very informative. The results made me change the design of the apartments (...), in part because I realised that a lot of single parents travel alone with their children (...). The changes I made were a direct consequence of the focus group interviews (...).'

Although non-pecuniary inflows of knowledge during these processes seemed to come most commonly from customers, informants also provided a few examples of such inflows from other firms in the value network. Our findings suggest that this often happened when collaboration with other firms was necessary to deliver the new service. For example, the informant from firm $M$ (cruise and transport shipping firm) explained how they developed a new experiential service (perceived to have a high degree of newness) together with another firm:

'I can mention an example of a new experiential service we have developed for the German market. (...) To increase the number of German travellers we decided to collaborate with [anonymised], and we developed a new experiential service together that we called [anonymised]. (...) Our partner provided us with a lot of insight about their customers, which we used during the development of this new experiential service.'

The CEO of Firm A (hotel chain) provided another example illustrating a similar practice when they developed a new experiential service (perceived to have a high degree of newness): 
'After we decided what concept we wanted to offer, we sat down with a partner, in this case the provider of the specific experience product, and then we discussed how this concept could be realized in practice. (...) In this dialogue the partner came up with concrete ideas, while we came up with many requirements related to availability, service quality, safety and so on (...). Our requirements can often be a challenge for smaller players (...).'

The practices related to non-pecuniary inflows of knowledge during incremental new service development processes differed somewhat from those related to inflows during more radical service development. Although the incremental processes were very open in the early idea search stage, as described above, they were more closed during the development and implementation stages. For example, when explaining how firm $E$ had developed a new food concept (perceived to have a low degree of newness), one of the firm's hotel managers stated:

'After we had decided to go for this new food concept, the course and conference manager, the chef, the restaurant manager and I worked together. Only the four of us worked on it. (...) We talked about it and the chef made some suggestions, and we tasted and adjusted. But we did not involve anyone else during this process. Not until the new concept was launched (...).'

\section{Pecuniary inbound open innovation (acquiring)}

During the interviews, informants provided some examples of purposive pecuniary inflows of knowledge. In some innovation processes that were perceived to be radical, knowledge was acquired from suppliers, consultants, and research institutions to solve explicit problems during the development process. For example when we asked the CEO of firm $\mathrm{H}$ how they were able to find members for the focus groups used during the development of the previously mentioned new themed accommodation concept, he stated:

'We did this in cooperation with a consultant named [anonymised]. He was an expert in loyalty development (...). So, he was given access to our customer databases (...) and based on the information in the databases he was able to identify a sample of customers who should be invited to participate in focus groups (...).'

Firm E also acquired external knowledge when they developed a new conference concept. A hotel manager explained:

'When the new concept gradually began to be pretty clear, we came to the conclusion that we needed to collaborate with an external party which can in a way certify us and give us advice (...). And then we decided to make an agreement with [anonymised], and we have had a good collaboration with them (...).' 
Strikingly, few pecuniary inflows of knowledge of this kind were identified in innovation processes that informants perceived to have low degrees of newness.

\section{Non-pecuniary outbound open innovation (revealing)}

Our findings suggest that tourism firms occasionally purposively revealed internal knowledge to external actors, with the intention to accelerate these actors' innovation. This practice may be illustrated with the following statement from the informant from firm $M$ :

'Since a lot of the tourists that come to Norway travel with our ships we have a lot of detailed insight about what tourists travelling to Norway need and request. We are very willing to share this information with firms that are providing experiences for tourists in Norway so that these firms are able to improve their products and services. We believe that in the long run both we and they will benefit from this since better experiential services will generate more satisfied customers which in turn will result in more repurchase.'

In the examples identified during our interviews, firms sharing knowledge with external parties were not paid directly. However, informants expressed the expectation that the sharing of knowledge would result in increased sales for both parties in the long term. This may be illustrated with the following statement of the same informant from firm $M$ :

'We do not share what we know with everyone. We have to be sure that the party receiving the knowledge is able to use this knowledge to actually innovate and improve its products. If we are not sure about this we will neither share nor collaborate. We do not want our brand to be associated with firms that do not deliver what the customers expect.'

\section{Pecuniary outbound open innovation (selling)}

We identified no example of a tourism firm in our sample selling knowledge to an external party.

\section{DISCUSSION}

We started this paper by asking the research question: what types of open innovation practice are utilised during the development of new tourism services? Based on a review of the open (product) innovation literature, Dahlander and Gann (2010) identified four types of open innovation practice: 1) inbound non-pecuniary, 2) inbound pecuniary, 3) outbound non-pecuniary, and 4) outbound pecuniary. 
In our interview data, we identified the first three types of open innovation, but we were not able to identify an example of outbound pecuniary open innovation. Research has suggested that outbound pecuniary open innovation is an important opportunity for manufacturing firms that aim to benefit from their R\&D activities (Huizingh, 2011). However, traditional service firms have seldom been included in empirical studies of outbound pecuniary open innovation. Previous empirical research has suggested that the intangible nature of services complicates modularisation (de Brentani, 2001; Aas \& Pedersen, 2013), and conceptual research has suggested that this implies that the identification of tangible knowledge modules that may be sold in outbound pecuniary open service innovation processes may be difficult (Aas \& Pedersen, 2016). Thus, given the characteristics of services in general, and tourism services in particular, it may not be surprising that we are unable to find examples of outbound pecuniary open innovation in tourism. In fact, our findings confirm the ideas of prior conceptual research (e.g., Aas and Pedersen, 2016). Thus, we offer proposition (P) 1:

P1: It is difficult for tourism firms to sell outflows of knowledge to external actors in pecuniary outbound open innovation processes.

However, we found several examples of non-pecuniary outflows of knowledge in our cases. In particular, our findings indicate that tourism firms decided to share internal knowledge with other tourism firms when both parties would benefit in the long run. Previous researchers have argued that the existence of incentives is a success factor for outbound non-pecuniary open innovation (Henkel, 2006; West \& Gallagher, 2006). Although the relevance of outbound non-pecuniary open innovation has been given limited attention in prior tourism innovation research, research has suggested that tourism firms in a given region typically have natural interdependencies because they share the same customers (Fosse \& Normann, in press). Thus, from a conceptual viewpoint it may be argued that tourism firms in this network often have long-term incentives for sharing knowledge with each other, even when the allocation of a monetary value to a specific knowledge outflow may be difficult. Our findings contribute to the current understanding by providing empirical evidence to this conceptual idea. Hence, we offer P2:

P2: Tourism firms reveal knowledge to other tourism firms when the firms providing the knowledge and those receiving it will both benefit in the long run.

Our findings suggest that the tourism firms in our sample utilised pecuniary and non-pecuniary inflows of knowledge during their service innovation 
processes. This finding confirms the findings of prior empirical research on innovation in tourism (Hjalager, 2010). However, our findings also supplement the findings of prior research considerably by showing that the stage of the innovation process at which inflows of knowledge were used varied systematically with respect to whether the innovation process was perceived to be incremental or more radical. We used informants' perceptions of whether innovations were radical or incremental, although more formal definitions of these concepts exist in the innovation management literature (Henderson \& Clark, 1990; Gallouj \& Weinstein, 1997). Gallouj and Weinstein (1997), for example, define a radical new service as a simultaneous change in the service, technical, and competence dimensions. Whether all innovations perceived to be radical by our informants comply with such a strict definition is questionable. Nevertheless, we argue that the informants' perceptions reflect whether specific innovations had high or low degrees of newness.

External sources were utilised to some degree in the early ideaidentification stages of the innovation processes perceived to be radical, but very indirectly, as sources of inspiration. Concrete ideas and opportunities were specified internally in most cases. Thus, firms in our sample rarely utilised purposive inflows of knowledge at the front ends of innovation processes perceived to be radical. Compared with previous research, this finding is somewhat surprising. Previous reports have suggested that external actors, such as users (Skiba, 2009), can be sources of radical new ideas in the service sector. We suspect, however, that our finding may be explained by the specific characteristics of tourism services, which are arguably always co-created (Zeithaml et al., 1985; Gustafsson et al., 2012). Thus, the development of radically new ideas may require possession of indepth insight about internal firm characteristics, such as employees' skills and the firm's vision and financial resources, as well as about market and customer characteristics. Internal firm employees may be more likely than external actors, such as customers, to possess this combination of insights.

However, in the later stages of (perceived) radical development processes, our findings suggest that firms often made use of purposive inflows of knowledge. Detailed insight and knowledge from existing and prospective customers, as well as external firms (e.g., consultancy firms), were used to design and develop radical new services. This practice may be explained by the concrete and tangible nature of the external knowledge needed during the development process, compared with that needed at the front end; such knowledge can be acquired from or revealed by external actors. Inflows of knowledge from other firms (e.g., consultants) were typically pecuniary, whereas those from customers were typically non-pecuniary. The reason for this difference may be that customers have 'self-interest' in participating in 
the development process, as they are future users of the new service. We thus offer P3:

P3: When radical new tourism services are developed, pecuniary and nonpecuniary purposive inflows of knowledge are utilised more typically during the development stage than at the front end of the innovation process.

Inflows of knowledge were also used during innovation processes perceived to be incremental. However, our findings indicate that knowledge from external parties was typically utilised at the front end of incremental service innovation. This finding is perhaps not surprising, as customers are particularly qualified to make suggestions for improvement of the services they are experiencing. As customers have 'self-interest' in service improvement, the typically nonpecuniary nature of these inflows of knowledge is not surprising. We found limited use of inflows of knowledge in the later stages of incremental service innovation processes, perhaps due to the low complexity of existing service improvement compared with the development of a completely new service. We thus offer P4:

P4: When new incremental tourism services are developed, non-pecuniary purposive inflows of knowledge are typically utilised at the front end of the innovation process.

The four propositions are summarised in Table 2.

Table 2. The utilisation of open innovation types during new tourism service development

\begin{tabular}{lll}
\hline & \multicolumn{1}{c}{ Inbound } & \multicolumn{1}{c}{ Outbound } \\
\hline Pecuniary & $\begin{array}{l}\text { Utilised in the development stage of Difficult to utilise (P1) } \\
\text { radical innovation processes (P3) }\end{array}$ \\
$\begin{array}{ll}\text { Non-pecuniary } \\
\text { Utilised in the development stage } \\
\text { of innovation processes (P3, P4) } \\
\text { and at the front end of incremental } \\
\text { innovation processes (P4) }\end{array}$ & $\begin{array}{l}\text { Utilised when the actors providing } \\
\text { and receiving the knowledge benefit } \\
\text { in the long term (P2) }\end{array}$ \\
\hline
\end{tabular}

\section{CONCLUSIONS}

This paper has empirically explored the types of open innovation practice utilised during service innovation processes in tourism. The findings suggest that pecuniary and non-pecuniary inflows of knowledge are utilised. However, the stage of the innovation process during which inflows of 
knowledge were utilised varied systematically with respect to whether the process was perceived to be incremental or more radical. The findings also showed that tourism firms reveal knowledge to other tourism firms in nonpecuniary outbound open innovation processes. No example of pecuniary outbound open innovation was identified in our study. Thus, we argue that pecuniary outbound open innovation may be difficult for tourism firms to utilise. These findings may be of assistance for managers of tourism firms aiming to utilise open innovation, as they may aid decisions about what types of such innovation to implement.

We believe that we were able to identify typical open innovation practices implemented by tourism firms by purposely selecting innovative tourism firms and by using a qualitative in-depth approach. Tourism represents the subsector of service delivery characterised by intangibility, heterogeneity, inseparability, and perishability, and we believe that the findings are applicable to other firms delivering services with the same characteristics. Nevertheless, due to the limitations with qualitative studies we were not able to test this suggestion. Due to this limitation, and due to the fact that recent research has indicated that the characteristics of services, as well as those of innovation practices, differ considerably among service subsectors (Kuester et al., 2013), we suggest that future research examine the propositions offered in this paper empirically in other service subsectors. Continued exploration of different types of service firm and empirical examination of the propositions offered in this paper will enhance our understanding of open service innovation practices.

Another more general limitation with non-experimental research, such as this study, is that it is only able to describe and evaluate present practice (e.g., Gerring and McDermott, 2007). Thus, based on our study we were not able to discuss whether alternative open innovation practices would be more beneficial for the case organisations. We therefore suggest that future research should investigate whether firms could also benefit from the implementation of other types of open service innovation practices than identified in our study.

\section{Acknowledgement}

Financial support from the Norwegian Research Council (research grant \#227026/O50) is gratefully acknowledged. 


\section{References}

Aas, T. H., \& Pedersen, P. E. (2010). The firm-level effects of service innovation: a literature review. International Journal of Innovation Management, 14(5), 759-794.

Aas, T.H., \& Pedersen, P.E. (2016). The feasibility of open service innovation. In A.L. Mention and M. Torkkeli (Eds.), Open Innovation: A Multifaceted Perspective, Vol. 1 (pp. 287-314). London, England: World Scientific Publishing.

Aas, T.H., \& Pedersen, P.E. (2013). The Usefulness of Componentization for Specialized Public Service Providers. Managing Service Quality: An International Journal, 23(6), 513-532.

Adams, R., Bessant, J., \& Phelps, R. (2006). Innovation management measurement: a review. International Journal of Management Reviews, 8(1), 21-47.

Adner, R., \& Kapoor, R. (2010). Value creation in innovation ecosystems: How the structure of technological interdependence affects firm performance in new technology generations. Strategic Management Journal, 31(3), 306-333.

Buhalis, D. (2000). The tourism phenomenon: the new tourist and consumer. In C. Wahab, and C. Cooper (Eds.), Tourism in the age of globalization (pp. 69-96). London, England: Routledge.

Carbonell, P., Rodríguez-Escudero, A., \& Pujari, D. (2012). Performance effects of involving lead users and close customers in new service development. Journal of Services Marketing, 26(7), 497-509.

Chesbrough, H.W. (2003). The era of open innovation. MITSloan Management Review, 44(3), 35-41.

Chesbrough, H.W. (2011a). Open Services Innovation: Rethinking Your Business to Grow and Compete in a New Era. San Francisco, CA: Jossey-Bass.

Chesbrough, H.W. (2011b). The Case for Open Services Innovation: The Commodity Trap. California Management Review, 53(3), 5-20.

Chesbrough, H., Vanhaverbeke, W., \& West, J. (2006). Open innovation: Researching a new paradigm. London, England: Oxford University Press.

Dahlander, L., \& Gann, D. M. (2010). How open is innovation? Research policy, 39(6), 699-709.

de Brentani, U. (2001). Innovative versus incremental new business services: different keys for achieving success. Journal of Product Innovation Management, 18(3), 169-187.

de Jong, J.P.J., Bruins, A., Dolfsma, W., \& Meijgaard J. (2003). Innovation in service firms explored: what, how and why? Strategic study B200205. Zoetermeer, Holland: EIM Business \& Policy Research.

de Jong, J., \& Vermeulen, P. (2003). Organizing successful new service development: a literature review. Management Decision, 41(9), 844-858.

den Hertog, P. (2000). Knowledge-intensive business services as co-producers of innovation. International Journal of Innovation Management, 4(4), 491-528. 
den Hertog, P., van der Aa, W., \& de Jong, M.W. (2010). Capabilities for managing service innovation: towards a conceptual framework. Journal of Service Management, 21(4), 490-514.

Drejer, I. (2004). Identifying innovation in surveys of services: a Schumpeterian perspective. Research Policy, 33(3), 551-62.

Droege, H., Hildebrand, D., \& Heras Forcada, M. A. (2009). Innovation in services: present findings, and future pathways. Journal of Service Management, 20(2), 131-155.

Evangelista, R. (2000). Sectoral patterns of technological change in services. Economics of Innovation and New Technology, 9, 182-221.

Evangelista, R., \& Vezzani, A. (2010). The economic impact of technological and organizational innovations. A firm-level analysis. Research Policy, 39(10), 1253-1263.

Fosse, J.K., \& Normann, R.H. (in press). Management Strategies in Cluster Projects - Examples and Discussions. In D. Fornahl and R. Hassink (Eds.), Cluster Policies from a Cluster Life Cycle Perspective. Cheltenham: Edward Elgar.

Gallouj, F., \& Weinstein, O. (1997). Innovation in services. Research Policy, 26(4/5), 537-556.

Gambardella, A., Giuri, P., \& Luzzi, A. (2007). The market for patents in Europe. Research Policy, 36(8), 1163-1183.

Gerring, J., \& McDermott, R. (2007). An experimental template for case-study research. American Journal of Political Science, 51(3), 688-701.

Gianiodis, P.T., Ettlie, J.E., \& Urbina, J.J. (2014). Open service innovation in the global banking industry: Inside-out versus outside-in strategies. The Academy of Management Perspectives, 28(1), 76-91.

Gustafsson, A., Kristensson, P., \& Witell, L. (2012). Customer co-creation in service innovation: a matter of communication? Journal of Service Management, 23(3), 311-327.

Hall, C.M. \& Williams, A.M. (2008). Tourism and innovation. London, England: Routledge.

Helfat, C.E.C. (2006). Book review of open innovation: the new imperative for creating and profiting from technology. Academy of Management Perspectives, 20(2), 86.

Henderson, R.M., \& Clark, K.B. (1990). Architectural Innovation: The Reconfiguration of Existing Product Technologies and the Failure of Established Firms. Administrative Science Quarterly, 35(1), 9-30.

Henkel, J. (2006). Selective revealing in open innovation processes: The case of embedded Linux. Research Policy, 35(7), 953-969.

Hjalager, A. (2000). Tourism destinations and the concept of industrial districts. Tourism \& Hospitality Research, 2(3), 199-213.

Hjalager, A. (2010). A review of innovation research in tourism. Tourism Management, 31(1), 1-12.

Huizingh, E.K. (2011). Open innovation: State of the art and future perspectives. Technovation, 31(1), 2-9. 
Hydle, K.M., Aas, T.H., \& Breunig, K.J. (2014). Characteristics of intrapreneurs in scale-intensive service firms. Journal of Entrepreneurship, Management and Innovation, 10(2), 89-118.

Johne, A., \& Storey, C. (1998). New service development: A review of the literature and annotated bibliography. European Journal of Marketing, 32(3/4), 184-251.

Johnson, P., \& Harris, D. (2003). Qualitative and Quantitative Issues in Research Design. In D. Partington (Ed.), Essential Skills for Management Research (pp. 99-134). London, England: Sage Publications.

Johnson, S.P., Menor, L.J., Roth, A.V., \& Chase, R.B (2000). A critical evaluation of the new service development process. In J.A. Fitzsimmons \& M.J. Fitzsimmons (Eds.), New service development: Creating memorable experiences (pp. 1-32). Thousand Oaks, CA: Sage Publications.

Kuester, S., Schuhmacher, M. C., Gast, B., \& Worgul, A. (2013). Sectoral Heterogeneity in New Service Development: An Exploratory Study of Service Types and Success Factors. Journal of Product Innovation Management, 30(3), 533-544.

Lages, C., \& Piercy, N. (2012). Key drivers of frontline employee generation of ideas for customer service improvement. Journal of Service Research, 15(2), 215-230.

Laursen, K., \& Salter, A. (2004). Searching high and low: what types of firms use universities as a source of innovation? Research policy, 33(8), 12011215.

Menor, L.J., \& Roth, A.V. (2007). New service development competence in retail banking: construct development and measurement validation. Journal of Operations Management, 25(4), 825-846.

Menor, L.J., Tatikonda, M.V., and Sampson, S.E. (2002). New service development: Areas for exploitation and exploration. Journal of Operations Management, 20(2), 135-57.

Mention, A.L. (2011). Co-operation and co-opetition as open innovation practices in the service sector: which influence on innovation novelty? Technovation, 31(1), 44-53.

Meyer, J. (2010). Does social software support service innovation? International Journal of the Economics of Business, 17(3), 289-311.

Mina, A., Bascavusoglu-Moreau, E., \& Hughes, A. (2014). Open service innovation and the firm's search for external knowledge. Research Policy, 43(5), 853-866.

Nijssen, E. J., Hillebrand, B., Vermeulen, P.A., \& Kemp, R.G. (2006). Exploring product and service innovation similarities and differences. International Journal of Research in Marketing, 23(3), 241-251.

Nuvolari, A. (2004). Collective invention during the British Industrial Revolution: the case of the Cornish pumping engine. Cambridge Journal of Economics, 28(3), 347-363. 
Orfila-Sintes, F., Crespí-Cladera, R., \& Martínez-Ros, E. (2005). Innovation activity in the hotel industry: Evidence from Balearic Islands. Tourism Management, 26(6), 851-865.

Skiba, F. (2009). Users as sources for radical service innovations: opportunities from collaboration with service lead users. International Journal of Services Technology and Management, 12(3), 317-337.

Spohrer, J. (2008). Services sciences, management, and engineering (SSME) and its relations to academic disciplines. In B. Stauss, A. Kremer \& A. Luhn (Eds.), Services Science: Fundamentals, Challenges and Future Developments (pp. 11-40). Springer, Frankfurt.

Spohrer, J. \& Maglio, P.P. (2008). The emergence of service science: toward systematic service innovations to accelerate co-creation of value. Production \& Operations Management Society, 17(3), 238-246.

Stamboulis, Y., \& Skayannis, P. (2003). Innovation strategies and technology for experience-based tourism. Tourism Management, 24(1), 35-43.

Tsou, T. (2012). Collaboration competency and partner match for e-service product innovation through knowledge integration mechanisms. Journal of Service Management, 23(5), 640-663.

Vargo, S. L., \& Lusch, R. F. (2004). Evolving to a new dominant logic for marketing. Journal of Marketing, 68(1), 1-17.

Van Ark, B., Broersma, L., \& den Hertog, P. (2003). Service innovation, performance and policy: a review. Synthesis Report in the Framework of the Project Structural Informatievoorziening in Diensten (SIID). The Hague, Holland: Ministry of Economic Affairs.

West, J., \& Bogers, M. (2014). Leveraging External Sources of Innovation: A review of Research on Open Innovation. Journal of Product Innovation Management, 31(4), 814-831.

West, J., \& Gallagher, S. (2006). Challenges of open innovation: the paradox of firm investment in open-source software. $R$ \& D Management, 36(3), 319-331.

Williams, A. M., \& Shaw, G. (2011). Internationalization and innovation in tourism. Annals of Tourism Research, 38(1), 27-51.

Yin, R.K. (2003). Case Study Research-Design and Methods (3rd ed). Thousand Oaks, CA: Sage Publications.

Zeithaml, V.A., Parasuraman, A., \& Berry L.L. (1985). Problems and strategies in service marketing. Journal of Marketing, 49(2), 33-46.

Zomerdijk, L.G., \& Voss, C.A. (2011). NSD processes and practices in experiential services. Journal of Product Innovation Management, 28(1), 63-80.

\section{Appendix A - Interview guide}

1) What are your background and your role in the organisation?

2) Please give some examples of new or improved services introduced recently by your firm. 
3) Can you please select two new services introduced recently by your firm, and for each service explain a) where the idea came from (internal or external; if external, did you pay for it?), b) why the firm decided to invest in the development of the new service, c) how the development process was organised (did you collaborate with external parties?), d) what kinds of tool were used during the development process (e.g., social media, ICT tools), and e) how you measured the results of the development process?

4) Are the managerial practices related to the processes described in the previous question typical for the management of innovation processes in your organisation?

5) If possible, please give some examples of new or improved services introduced lately by other firms, where your firm has participated in the development.

6) Can you please select two new services introduced by other firms, where your firm has participated during the development process, and for each new service explain a) why you participated, b) how you participated (what was your role?), c) whether the innovating firm paid for your assistance, d) what kinds of tool were used (e.g., social media, ICT tools), and e) how your was participation evaluated?

7) Are the practices described in the previous question typical when your firm participates in other firms' innovation processes?

\begin{abstract}
Polish)
Większość badań empirycznych zwiqzanych z otwartymi innowacjami koncentruje się na rozwoju nowych produktów fizycznych w branżach produkcyjnych. Natomiast innowacyjność otwartych usług nie została odpowiednio zbadana. Usługi majq pewne cechy, które odróżniajq je od produktów fizycznych, które mogq mięć wpływ na rodzaje praktyki otwartej innowacji wykorzystywanych w procesach innowacyjnych usług. Usługi turystyczne obejmujq podzbiór usług, który jest istotnie różny od produktów materialnych. Dlatego badanie, jak firmy wykorzystuja rożne rodzaje turystyki w praktyce otwartej innowacji oferuje cennq możliwość poznania charakteru praktyk innowacyjnej usługi otwartej. Tak więc, artykuł ten odpowiada na następujq̨ce pytanie badawcze: jakie rodzaje praktyki otwartych innowacji wykorzystywane sq $w$ trakcie opracowywania nowych usług turystycznych? Jakościowe podejście z wykorzystaniem studium przypadku użyto tutaj, aby odpowiedzieć na pytanie badawcze. Odkrycia sugerujq, że materialne i niematerialne napływy wiedzy sq wykorzystywane $w$ procesach innowacyjnych usług $w$ turystyce. Jednakże etap procesu innowacji, $w$ którym zostały wykorzystane wpływy wiedzy zmienia się systematycznie w odniesieniu do tego, czy innowacja jest postrzegana jako przyrostowa lub bardziej radykalna. Wyniki wskazujq również, że firmy turystyczne ujawniajq wiedzę innych firm turystycznych wywodzqcych się z niematerialnych, otwartych procesów innowacyjnych. Jednak żaden z przykładów praktyki otwartych innowacji o charakterze niematerial-
\end{abstract}


nym nie został zidentyfikowany w tym badaniu. Implikacje dla zarzqdzania i dalszych badań sq omówione $w$ artykule.

Słowa kluczowe: innowacje usług, rozwój nowych usług, otwarte innowacje, zarzq̨dzanie turystykq.

\section{Biographical note}

Tor Helge Aas is an Associate Professor at the Department of Management, School of Business and Law, University of Agder, Norway and a Senior Researcher at Agderforskning AS, Norway. Dr. Aas has a PhD in strategy and management from the Norwegian School of Economics. He is conducting research in innovation management, management control, and strategic management, particularly in relation to the service sector. 
